\title{
Synestezja a sztuka, red. Aleksandra Rogowska, Julia Kaleńska-Rodzaj
}

DOI: $10.14746 / \mathrm{rfn} .2018 .19 .10$

Synestezja to stosunkowo rzadkie zjawisko. Częstotliwość jej występowania w ogólnej populacji określana jest w bardzo szerokich ramach (szacunki w różnych badaniach wskazywały od kilku promili do kilkunastu procent ${ }^{1}$ ) i zależy od zastosowanych metod i doboru grup badawczych - aktualne szacunki wskazują na $2-4 \%^{2}$. Doświadczenie synestetyczne obejmuje $\mathrm{w}$ ramach reakcji na stymulację bodźcem jednej modalności sensorycznej dodatkowe doświadczenia pochodzące $\mathrm{z}$ dwóch lub więcej modalności ${ }^{3}$ W percepcji osób doświadczających synestezji jest to jak najbardziej naturalne zjawisko, a odkrycie, że pozostała część populacji nie postrzega rzeczywistości w podobny sposób, jest dla synestetyka często zadziwiające ${ }^{4}$. W świadomości medycznej doświadczenie synestetyczne funkcjonuje od ponad 300 lat, choć analizy skupione na jego wyjaśnieniu są znacznie młodsze ${ }^{5}$. Współcześnie synestezja

D. Johnson, C. Allison, S. Baron-Cohen, The Prevalence of Synesthesia, [w:] Oxford Handbook of Synesthesia, red. J. Simner, E. Hubbard, Oxford 2013, s. 3-22.

2 J. Simner, C. Mulvenna, N. Sagiv, E. Tsakanikos, S.A. Witherby, C. Fraser, K. Scott, J. Ward, Synaesthesia: The Prevalence of Atypical Cross-Modal Experiences, „Perception” 2006 t. 35 nr 8, s. 1024-1033; G. Bargary, K.J. Mitchell, Synaesthesia and Cortical Connectivity, „Trends in Neurosciences” 2008 t. 31 nr 7, s. 335-342.

3 E.M. Hubbard, V.S. Ramachandran, Neurocognitive Mechanisms of Synaesthesia, „Neuron” 2005 t. 48 nr 3, s. 509-520; A. Rogowska, U źródeł synestezji: podstawy fizjologiczne i funkcjonalne, „Przegląd Psychologiczny” 2002 t. 45 nr 4, s. 465-474.

${ }_{4}^{4}$ R.E. Cytowic, Synesthesia: A Union of the Senses, Cambridge, Mass. 2002.

5 Ibidem. jest przedmiotem zainteresowania wielu badaczy reprezentujących różne dziedziny nauki, co znajduje swoje odzwierciedlenie w monografii Synestezja a sztuka pod redakcją Aleksandry Rogowskiej oraz Julii Kaleńskiej-Rodzaj. Pozycja ta składa się ze zbioru artykułów autorstwa badaczy synestezji w psychologii, muzyce i literaturze, jak i twórców doświadczających synestezji osobiście i wykorzystujących ją w swojej codziennej twórczej pracy. Dzięki temu analiza synestezji w recenzowanej monografii dokonana została $\mathrm{z}$ wielu perspektyw i pozwala czytelnikowi na wieloaspektowe spojrzenie na nią. W czterech częściach książki znajdują się artykuły poświęcone naukowej analizie zjawiska synestezji (w części Zjawisko synestezji w świetle badań psychologicznych), obecności synestezji w sztuce (Związki synestezji ze sztuka), jej przejawom w literaturze, zarówno z perspektywy osobistego doświadczenia twórców, jak i jej obecności w ich dziełach (Przejawy synestezji $w$ literaturze). Ostatnia część monografii poświęcona jest relacjom z pierwszej ręki na temat wykorzystania synestezji we własnej pracy twórczej (Wykorzystanie synestezji we własnej twórczości artystycznej).

W pierwszej części przedstawiono szereg koncepcji związanych z synestezją, kreśląc tym samym jej szeroki i bogaty obraz naukowy. W części tej znajdują się odniesienia do aktualnych badań naukowych, w tym również do badań własnych. Czytelnik dzięki lekturze tej części monografii może poznać hipotezy omawiające 
genezę oraz działanie tego zjawiska, jak również uświadomić sobie jego niezwykłą różnorodność.

W rozdziale autorstwa Justyny Skowronek $C z y$ jesteś synestetykiem? Typologia synestezji i sposoby jej diagnozowania czytelnik może zapoznać się z definicją synestezji oraz jej różnymi rodzajami. Autorka na podstawie obszernego przeglądu literatury przedstawia wybrane grupy synestezji oraz istniejące jej typologie, m.in. podział na synestezję poznawczą i właściwą, inter- i intramodalną czy projekcyjną i asocjacyjną. Opisując wybrane typy synestezji, przedstawia jej najczęstsze formy, takie jak grupa synestezji lingwistycznych czy chromostezja. W swojej analizie nie zapomina jednak o rodzajach rzadziej opisywanych, jak np. synestezja lustrzana (dotykowa), która pierwszy raz była zbadana na początku XXI wieku i stanowi aktualnie ciekawą inspirację dla naukowców wiążących jej występowanie ze zwiększoną empatią i działaniem neuronów lustrzanych ${ }^{6}$. Artykuł zakończony jest rozważaniami dotyczącymi diagnozowania synestezji oraz kryteriów odróżniania synestezji właściwej od nabytej w drodze zastosowania środków psychoaktywnych, epilepsji czy uszkodzenia mózgu. Rozdział ten pozwala rozpoznać podstawowe właściwości zjawiska synestezji i stanowi bardzo dobrą podstawę do dalszych rozważań przedstawionych w kolejnych częściach monografii.

W kolejnym rozdziale - Biologiczne podłoże synestezji - Karolina Czernecka, wykorzystując bogatą literaturę, analizuje biologiczne podstawy synestezji. Odnosząc się do badań, w których zastosowano techniki neuroobrazowania, przedstawia hipotezy dotyczące potencjalnych podstaw neuronalnych synestezji. W swojej analizie wyróżnia dwa podstawowe modele neuroplastyczne synestezji - zmian strukturalnych oraz zmian funkcjonalnych, które wyjaśniają genezę tego zjawiska. Poddaje te modele krytyce, zwracając uwagę zarówno na czynniki je potwierdzające, jak i podważające. Autorka odnosi się również do potencjalnych zmiennych, które powinny być kontrolowane ze względu na ich zakłócający charakter w badaniach z wykorzystaniem technik neuroobrazowania. Nie zostały jednak wykorzystane w tej dyskusji najnowsze

${ }^{6}$ M.J. Banissy, J. Ward, Mirror-Touch Synesthesia Is Linked with Empathy, „Nature Neuroscience” 2007 t. 10 nr 7, s. 815-16; O. Linkovski, N. Katzin, M. Salti, Mirror Neurons and Mirror-Touch Synaesthesia, „The Neuroscientist” 2017 t. 23 nr 2, s. 103-108. krytyczne analizy, np. przeprowadzona przez Hupé i Dojat ${ }^{7}$, która wskazuje, że zdecydowana większość badań synestezji metodą neuroobrazowania posiada słabą moc statystyczną, przeprowadzona była na zbyt małych próbach badawczych i posiada inne ograniczenia metodologiczne, które nie pozwalają na jednoznaczne sformułowanie wniosków. Wspomniana publikacja prowadzi do konkluzji, że, jak dotąd, środowisku naukowemu nie udało się wyodrębnić neuronalnych korelatów synestezji. Czernecka nie pozostawia jednak dotychczasowych badań bez krytycznego komentarza, zwraca też uwagę na konieczność rozwijania badań i wskazuje na istotne kierunki, które pozwoliłyby, być może, zweryfikować istniejące hipotezy oraz określić, czy synestezja jest zjawiskiem percepcyjnym czy pamięciowym.

Autorka rozdziału trzeciego: Czy synestezja jest normalna?, Aleksandra Rogowska, specjalizująca się w dziedzinie synestezji badaczka i autorka monografii Synaesthesia and Individual Differences, wydanej w roku 2015 przez Cambridge University Press, próbuje odpowiedzieć na pytanie: czy synestezja jest zjawiskiem normalnym. W swym rozdziale przedstawia kryteria, według których można wyróżniać synestezję. Zapoznaje też czytelnika $\mathrm{z}$ historią postrzegania synestezji jako zjawiska psychopatologicznego i powiązania jej z zaburzeniami, takimi jak halucynacje, z konsekwencjami zażycia substancji psychoaktywnych czy... praktykowania medytacji. Zwraca jednak uwagę na istotne odróżnienie doświadczenia synestetycznego od objawów psychopatologii i przedstawia argumentację za uznaniem synestezji za zjawisko wiążące się z międzymodalną percepcją. Autorka odwołuje się w rozdziale do własnej kompensacyjnej koncepcji synestezji - z tej perspektywy zjawisko to stanowi swoistą mnemotechnikę. Prezentując wyniki własnej pracy badawczej, z wykorzystaniem autorskiego „Testu skojarzeń językowo-kolorystycznych" (TSJK), potwierdza swoje hipotezy i przedstawia synestezje jako cechę ciagłą, która występuje w rzeczywistości w różnym natężeniu (zgodnie z krzywą Gaussa), jak równieżjako specyficzne skojarzenie międzymodalne mające charakter wysokiej mimowolności i abstrakcyjności. Autorka zauważa, że dotychczasowe badania nad synestezją najczęściej skupiały się jedynie na grupie

${ }^{7}$ J.-M. Hupé, M. Dojat, A Critical Review of the Neuroimaging Literature on Synaesthesia, „Frontiers in Human Neuroscience” 2015 t. 9 , art. 103 , s. 1-37. 
osób doświadczających tego zjawiska w sposób ekstremalny, w kontrze do osób w ogóle jej niedoświadczających, co może wpływać na nietrafne opisywanie rzeczywistej obecności synestezji w populacji. Carmichael, Down, Shillcock, Eagleman i Simner ${ }^{8}$, którzy analizowali trafność baterii do diagnozowania synestezji, również zauważają, że sposób doboru próby w dotychczasowych badaniach może prowadzić do łatwiejszego i bardziej wyrazistego zróżnicowania badanych, co niekoniecznie musi odpowiadać rzeczywistości. Rozdział Aleksandry Rogowskiej porusza tym samym tematykę synestezji od strony znacznie rzadziej analizowanej, a jednocześnie wykazującej ogromny potencjał w tym obszarze badawczym.

W drugiej części książki znajdują się artykuły traktujące o relacjach pomiędzy sztuką a synestezją. Rozdział autorstwa Iryny Boychuk - Synestezja jako klucz do poszerzonego odbioru, poznawania i twórczości $w$ różnych dziedzinach sztuki - poświęcony jest muzyce wizualnej i jej związkom z synestezją w zakresie zarówno percepcji, jak i procesu twórczego. W swoim przeglądzie literatury oraz analizach autorka prezentuje przejawy łączenia muzyki z kolorami i obrazem w różnych dziełach i traktatach, poczynając od prac starożytnych filozofów Arystotelesa i Pitagorasa, przez rozważania Newtona, do twórczości takich kompozytorów, jak Skriabin czy Rimski-Korsakow. Przywołuje również szereg przykładów obecności tego połączenia w sztuce, sięgając do nowszych zjawisk związanych z muzyką w kinematografii i do współczesnych twórców, jak Gamma Skupinsky. Dzięki tej pracy czytelnik może zobaczyć, w jaki sposób w sztuce powiązania pomiędzy poszczególnymi zmysłami człowieka mogą być wykorzystane zarówno w procesie twórczym, jak i w samym odbiorze dzieła.

Z kolei Joanna Ganczarek w rozdziale Synestezja $w$ malarstwie jako doświadczenie protomentalne opisuje obecną w malarstwie synestezję protomentalną, charakterystyczną dla reakcji zmysłu prioprioceptywnego na dzieło malarskie, objawiającą się m. in. napięciami w ciele. Nawiązując do rozważań Kandinsky'ego, autorka przedstawia synestezję jako swojego rodzaju metaforę obecną w odbiorze dzieła sztuki. Połączenie dźwięków,

8 D.A. Carmichael, M.P. Down, R.C. Shillcock, D.M. Eagleman, J. Simner, Validating a Standardised Test Battery for Synesthesia: Does the Synesthesia Battery Reliably Detect Synesthesia?, „Consciousness and Cognition" 2015 t. 33, s. 375-385. barwy, ale też ruchu wydaje się niecodziennym zjawiskiem, nawet dla doświadczenia synestetycznego. Autorka konsekwentnie przeprowadza jednak analizę z perspektywy tych połączeń, odnosząc się do rozważań artystów oraz do dzieł sztuki, jak również do metaforycznej funkcji synestezji w pracach artystycznych. Nawiązuje tutaj do psychofizjologicznego modelu Ruggierego, który niestety opisany jest jedynie w literaturze włoskiej, co stanowi pewne utrudnienie dla czytelnika, gdyby podjął on wyzwanie zrozumienia podstaw badawczych tej koncepcji. Podstaw synestezji protomentalnej upatruje autorka w teoriach Einfühlung, dekodowania imitacyjnego oraz ucieleśnionej symulacji, które znajdują swoje wyjaśnienie w kolejnych częściach jej rozdziału.

Trzecia i czwarta część monografii poświęcone są aspektowi artystycznemu synestezji: jej przejawom $\mathrm{w}$ literaturze oraz wykorzystaniu jej we własnej pracy twórczej artystów. Anna Ginter i Zuzanna Kozłowska przybliżyły czytelnikowi synestetyczne aspekty twórczości Vladimira Nabokova i Haliny Poświatowskiej. W rozdziale Anny Ginter - Barwne synestezje Vladimira Nabokova - czytelnik może znaleźć wiele przykładów z własnych relacji Nabokova opisujących jego doświadczenia, dla których prawdopodobnie można wskazać, według autorki, naukowe odpowiedniki w postaci synestezji leksykalnej, kognitywnej, pojęciowej bądź ideostezji. Praca autorki przybliżyła te doświadczenia, czerpiąc z samego źródła - autobiografii Nabokova, jak również jego innych wypowiedzi, dodała równocześnie głęboką analizę tych doświadczeń z perspektywy wiedzy o synestezji i jej typach. Bogactwo doświadczeń synestetycznych, takich jak doświadczanie kolorów smaku, dotyku czy bólu, zostało w tej pracy uwidocznione dzięki przytoczeniu fragmentów dzieł Nabokova odnoszących się do przeżyć bohaterów. Autorka nie pomija też polisensorycznych doświadczeń synestetycznych, które również znajdują swoje miejsce w dziełach pisarza. Dzięki pracy Anny Ginter czytelnik ma możliwość poznania źródeł bogatej palety barw wykorzystywanej przez Nabokova w jego dziełach, co może przyczynić się do lepszego zrozumienia jego twórczości.

Zuzanna Kozłowska w rozdziale Synestezyjna poezja Haliny Poświatowskiej przygląda się bogatemu językowi synestetycznemu obecnemu w poezji Haliny Poświatowskiej. Autorka wskazuje wiele odniesień do synestezji, które nauka określa jako grafem-kolor, 
leksem-wizja czy grafem-dotyk, podając jednocześnie wiele przykładów w twórczości poetki, umożliwiających czytelnikowi rozpoznanie tych niezwykłych połączeń w jej poezji.

W ostatniej części monografii, w artykułach autorstwa Szymona S. Strzelca, Anny Sztwiertni, jak również Moniki Kozakiewicz oraz Marty Mołodyńskiej -Wheeler, zostały zaprezentowane wyniki działania synestezji we własnej pracy twórczej autorów. To wyjątkowa część książki, dzięki której czytelnik może poznać synestezję niejako od kuchni i przybliżyć się do tego doświadczenia przez opisy własnych przeżyć autorów.

Szymon S. Strzelec i Anna Sztwiertnia są autorami rozdziału o wiele mówiącym tytule: Tysiące odcieni czerni. Synestezja wielomodalna jako mechaniczna podstawa rozumienia w komunikacji i twórczości artystycznej. Szymon Strzelec jest obdarzony tytułową synestezją wielomodalną, która powoduje u niego połączenie zmysłów dotyku, słuchu, wzroku i węchu. Co ciekawe, autor zwraca uwagę na stały rozwój doświadczeń synestetycznych, nabywanie nowych połączeń oraz na możliwość wykorzystania synestezji w charakterze swoistej strategii pamięciowej. Wskazane przez niego sposoby rozwoju synestetycznych przeżyć i wzbogacania palety połączeń, których doświadcza, idą w parze z aktualnymi koncepcjami synestezji, które wskazuja na jej wyuczony charakter oraz specyficzną funkcje jako strategii radzenia sobie $\mathrm{w}$ procesie uczenia się w dzieciństwie ${ }^{9}$. Dzięki jego analizom czytelnik uzyskuje wgląd w możliwości, jakie daje synestezja w twórczości artystycznej, jak również w to, jakie może powodować ograniczenia. Druga część rozdziału, autorstwa Anny Sztwiertni, poświęcona jest opisowi projektu artystycznego, który wykorzystywał kompozycje muzyczną Szymona Strzelca oraz jego doświadczenia synestetyczne związane z dźwiękiem. Analizowany 30-sekundowy fragment utworu został przez autorkę przełożony na język grafiki, co zaowocowało 30 grafikami, które jednak nie były odzwierciedleniem dźwięków sekunda po sekundzie. W ostatniej części rozdziału głos znów wraca do Szymona Strzelca, który podsumowuje swoje przeżycie i przedstawia rozważania na temat możliwości, jakie daje doświadczenie synestetyczne we współczesnej twórczości artystycznej,

9 N.R. Watson, K. Akins, C. Spiker, L. Crawford, J.T. Enns, Synesthesia and Learning: A Critical Review and Novel Theory, „Frontiers in Human Neuroscience" 2014 t. 8, art. 98, s. 1-15. otwierając przed twórcami i odbiorcami sztuki wiele wydawałoby się niedostępnych dróg.

Monika Kozakiewicz, autorka rozdziału Barwna emanacja sztuki. Wykorzystanie polimodalnej synestezji w twórczości muzycznej i poetyckiej, przedstawia nie tylko swoje własne doświadczenia synestetyczne, ale dokonuje również analizy obecności synestezji w twórczości Aleksandra Skriabina i Oliviera Messiaena. Opis tych przypadków oraz odniesienie się do pacjentów, których doświadczenia synestetyczne relacjonował w swojej bestsellerowej książce Muzykofilia Oliver Sacks, stanowią swoistą refleksję nad rolą synestezji w życiu twórcy. Są one też pewnego rodzaju wstępem do części, w której autorka przedstawia swoje przeżycia synestetyczne i ich funkcję we własnej twórczości muzycznej i literackiej. Barwne słyszenie pełni w życiu artystycznym autorki wiele funkcji. $Z$ jednej strony pozwala jej na wyjątkowe odbieranie dzieł muzycznych, wzbogacając tym samym ich przeżycie, $\mathrm{z}$ drugiej pełni również ważną funkcję w interpretacji i wykonawstwie utworów, dodając do nich wrażenia estetyczne zwiększające odczuwaną przyjemność. Autorka opisuje swoje barwne postrzeganie muzyki na konkretnych przykładach, zapraszając czytelnika do swojego wyjątkowego świata. Rola synestezji w procesie tworzenia muzyki jest $\mathrm{u}$ autorki niebagatelna. Opis kompozycji Le chuchotement de Daimonion zawiera wiele odniesień do połączeń wielomodalnych. Autorka opisuje również obecność synestezji leksykalnej w swojej poezji i przedstawia szereg przykładów odnoszących się do jej twórczości; wskazuje też czytelnikowi, co synestezja może powodować $\mathrm{w}$ procesie twórczym.

Monografia zakończona jest rozdziałem Marty Mołodyńskiej-Wheeler Synestezja - implikacje praktyczne w pracy muzyka i anglisty. Autorka $\mathrm{z}$ własnej perspektywy potwierdza - co poruszał też Cytowic ${ }^{10}$ nieświadomość u synestetyków tego, że inni mogą synestezji nie doświadczać. Synestezja jest dla niej interesującym i złożonym zjawiskiem, które trudno czasem ująć w słowa, co autorka pokazuje m.in. na przykładzie próby odpowiedzi na pytanie o kolor, w jakim widzi imię swojego rozmówcy. Autorka w sposób systematyczny analizuje własne widzenie barwne, wskazując podobieństwa i różnice pomiędzy literami, imionami czy nazwami dni tygodnia. Wnikliwa

\footnotetext{
${ }^{10}$ R.E. Cytowic, Synesthesia..., op. cit.
} 
analiza i graficzne przykłady sprawiają, że czytelnikowi łatwiej jest wyobrazić sobie świat, w którym autorka na co dzień funkcjonuje. Jej odniesienia do wspólnych elementów w słowach widzianych przez nią $\mathrm{w}$ określonych kolorach znajdują odpowiednik we współczesnych analizach badawczych, które sugerują, że za powstawanie konotacji synestetycznych mogą być odpowiedzialne semantyczne mechani$\mathrm{zmy}^{11}$. W podobny sposób, w jaki opisuje autorka kolorowe widzenie liter i wyrazów, przygląda się ona również swojemu barwnemu słyszeniu. Rozdział zakończony jest analizą pozytywnych i negatywnych stron synestezji w codziennym życiu. Wśród zalet znajduje się szereg zastosowań synestezji w procesach zapamiętywania (np. słów w nauce języków obcych czy numerów telefonu), jak również wzbogacenie interpretacji i odbioru dzieła muzycznego. $\mathrm{Z}$ kolei do wad autorka zalicza interferencję tego, co podpowiada pamięć, wspomagana przez synestetyczne doświadczenie, i tego, jaka jest aktualna rzeczywistość. Przykładem może być trudność z przestawieniem się na inną tonację podczas grania akompaniamentu czy z zapamiętaniem imienia osoby, której ubiór kolorystycznie nie współgra z kolorem imienia. Ten sposób przedstawienia swoich własnych doświadczeń pozwala czytelnikowi zrozumieć złożoność doświadczeń, które na co dzień towarzyszą synestetykom.

Monografia Synestezja a sztuka wprowadza czytelnika w świat nauki i jednocześnie świat osobistego doświadczenia. Dzięki relacjom poświęconym różnorodnym aspektom synestezji możliwe jest szerokie zrozumienie zjawiska nie tylko z perspektywy naukowej, ale również własnego przeżycia autorów tekstów w pracy zawartych. Eklektyczne ujęcie synestezji w odniesieniu do jej podstaw naukowych, ale też do dzieł literackich, muzyki czy malarstwa, sprawia, że monografia ma charakter pełny. Pokazuje kompletny obraz zjawiska zmysłowego poddawanego analizom naukowym, a jednocześnie nieco tajemniczego i niesamowitego. Z pewnością to pozycja warta uwagi, szczególnie osób, które na synestezję chcą spojrzeć z różnych perspektyw i zrozumieć nie tylko to, co o jej mechanizmach ma do powiedzenia nauka, ale również wejść na chwilę do synestetycznego świata. Cytowana

11 A. Mroczko-Wąsowicz, D. Nikolić, Semantic Mechanisms May Be Responsible for Developing Synaesthesia, „Frontiers in Human Neuroscience" 2014 t. 8, art. 509, s. 1-13. literatura, z której korzystają autorzy rozdziałów, może być także źródłem inspiracji dla czytelnika.

\section{BIBLIOGRAFIA}

Banissy Michael J., Ward Jamie, Mirror-Touch Synesthesia Is Linked with Empathy, „Nature Neuroscience” 2007 t. 10 nr 7, s. 815-816.

Bargary Gary, Mitchell Kevin J., Synaesthesia and Cortical Connectivity, „Trends in Neurosciences” 2008 t. $31 \mathrm{nr} 7$, s. 335-342.

Carmichael Duncan A., Down Matthew P., Shillcock Richard C., Eagleman David M., Simner Julia, Validating a Standardised Test Battery for Synesthesia: Does the Synesthesia Battery Reliably Detect Synesthesia?, „Consciousness and Cognition" 2015 t. 33, s. 375-385.

Cytowic Richard E., Synesthesia: A Union of the Senses, MIT Press, Cambridge, Mass. 2002.

Hubbard Edward M., Ramachandran Vilayanur S., Neurocognitive Mechanisms of Synaesthesia, „Neuron” 2005 t. 48 nr 3, s. 509-520.

Hupé Jean-Michel, Dojat Michel, A Critical Review of the Neuroimaging Literature on Synaesthesia, „Frontiers in Human Neuroscience” 2015 t. 9, art. 103, s. 1-37.

Johnson Donielle, Allison Carrie, Baron-Cohen Simon, The Prevalence of Synesthesia, [w:] Oxford Handbook of Synesthesia, red. Julia Simner, Edward Hubbard, Oxford University Press, Oxford 2013, s. 3-22.

Linkovski Omer, Katzin Naama, Salti Moti, Mirror Neurons and Mirror-Touch Synaesthesia, „The Neuroscientist” 2017 t. $23 \mathrm{nr} 2$, s. $103-108$.

Mroczko-Wąsowicz Aleksandra, Nikolić Danko, Semantic Mechanisms May Be Responsible for Developing Synaesthesia, „Frontiers in Human Neuroscience” 2014 t. 8, art. 509, s. 1-13.

Rogowska Aleksandra, $U$ źródeł synestezji: podstawy fizjologiczne i funkcjonalne, „Przegląd Psychologiczny” 2002 t. $45 \mathrm{nr} 4$, s. $465-474$.

Simner Julia, Mulvenna Catherine, Sagiv Noam, Tsakanikos Elias, Witherby Sarah A., Fraser Christine, Scott Kirsten, Ward Jamie, Synaesthesia: The Prevalence of Atypical Cross-Modal Experiences, „Perception” 2006 t. 35 nr 8, s. 1024-1033.

Watson Marcus R., Akins Kathleen, Spiker Chris, Crawford Lyle, Enns James T., Synesthesia and Learning: A Critical Review and Novel Theory, „Frontiers in Human Neuroscience" 2014 t. 8 , art. 98, s. 1-15. 